\title{
Bo Elling
}

\section{Borgerne som modmagt i planlægningen}

Artiklen fremstiller en kommunikativ planteori, hvori borgernes magt anskues som en ressource, der fremmer langsigtethed i modsætning til kortsigtede investorinteresser i den offentlige planlægning. Først skitseres tre overordnede planparadigmer - traditionel synoptisk, inkrementel og deltagerorienteret planlægning. Hertil føjes en kritisk diskussion af forskellige teorier inden for det sidstnævnte. I lyset heraf hævdes det, at planlæggende myndigheder oftest ser borgerdeltagelsen som et problem frem for et potentiale. Artiklen gør op med et sådant syn og bestemmer a) planbegrebet ud fra en habermasiansk teori om den kommunikative handlen og magt, b) viser, at borgernes deltagelse er nødvendig for at sikre de etiske og æstetiske rationaliteters inddragelse i planprocessen, og c) at borgerne kan udgøre en modmagt til kortsigtede investorinteresser i planlægningen, ved d) at styrke hensynet til langsigtede løsninger og almene goder. Derved bliver kommunikativ planlægning en alternativ position hvad angår magt. Dette ses som en strukturel nødvendighed til sikring af bæredygtighed og demokratisk retfærdighed i planlægningen. Artiklen begrebsliggør forskellen på planlægning og politik og viser, hvorfor magt må begribes forskelligt i de to tilfælde, da magt i det førstnævnte konstitueres i den aktuelle proces og ikke er givet på forhånd. Det gør det muligt for borgerne at påvirke planprocessen på en meget mere direkte facon.

Søgeord: borgerdeltagelse, kommunikativ rationalitet, planlægningshandlinger, borgernes modmagt, legitimitet. 
$\mathrm{D}$ enne artikel er et bidrag til en ny teori om borgerdeltagelse i den fysiske planlægning, hvor borgerne tildeles en mere eksplicit rolle i planlægningsprocessens konstituering af magt. Den argumenterer for, at langsigtede og bæredygtige plantiltag i globaliseringens tidsalder ikke kan gennemføres uden, at borgerne gives mulighed for at konstituere en sådan "borgermagt" eller modmagt. Den kan ses som et opgør med hidtidig tænkning om borgerdeltagelse, som mestendels ser borgernes deltagelse som et spørgsmål om supplerende viden i processen og demokratisk retfærdighed. Tænkningen kritiseres for $\mathrm{i}$ alt for høj grad kun at fokusere på planprocessens vidensskabende dialog, hvorimod magtudøvelsen forsømmes, og for at den i alt for ringe grad, hvis overhovedet, beskæftiger sig med den magt, som udøves i planlægningens beslutningsfase. Kritikken udtrykker således også en afgørende tillid til borgernes evne til at udøve fornuft og til at se de langsigtede kollektive interesser i den fysiske planlægnings mange vitale spørgsmål. Dette syn på borgerne adskiller sig også fra en udbredt skepsis - for ikke at sige træthed - inden for mange af planlægningens faggrupper, hvor en sådan tillid ofte mangler. Den gør også op med et udpræget fokus på behovet for ledelse og styring og en tiltagende hierarkisk opbygning af de offentlige institutioner, herunder planlægningens. Hensigten er ikke at udtrykke mistillid til den enkelte faglige planlægger, men at give denne "fri" - ikke kun fra ledelsesmæssig dominans, men også fra de overmåde stærke økonomiske kræfter, der i form af ejendoms- og investorkapital er blevet en næsten urørlig magtfaktor i samfundenes udvikling.

Kritikken af den blotte fokusering på dialogen i planlægningen har mere eksplicit afsæt i den engelske planlægningsteoretiker Patsy Healey's teorier om collaboratory planning og i hendes anvendelse af Habermas' begreber om kommunikativ rationalitet og diskursetik. Der argumenteres for, at hun har misforstået dem begge. Der kunne også refereres til de mange danske bidrag om behovene for borgerdeltagelse i planlægningen og forsøgene på at give sociologisk tænkning på området en form for oprejsning eller blot øget opmærksomhed. F.eks. i bogen Planlægning $i$ teori og praksis, hvor redaktørerne har en ellers glimrende indledende artikel (Jensen, Andersen, Hansen, Nielsen 2007:9-27), som imidlertid lider af de samme mangler, som det deltagerorienterede planparadigme kritiseres for. Samme bog indeholder en artikel med titlen "Kommunikativ planlægningsteori - nye idealer for borgernes rolle i planlægningen" (Agger 2007:31-45), der ligesom Patsy Healey refererer til Habermas' begreber om kommunikativ rationalitet og hans diskursetik - og begår de samme fejltagelser. Den formår ikke at overskride en blot "rationalistisk" forståelse af Habermas' begreb om kommunikativ rationalitet. Derfor kan den heller ikke opstille et alternativ til ovennævnte forståelse af borgerdeltagelsen.

Nærværende artikel tager eksplicit afsæt i en anden forståelse af Habermas' kommunikative rationalitet og magt og forsøger derigennem at opstille 


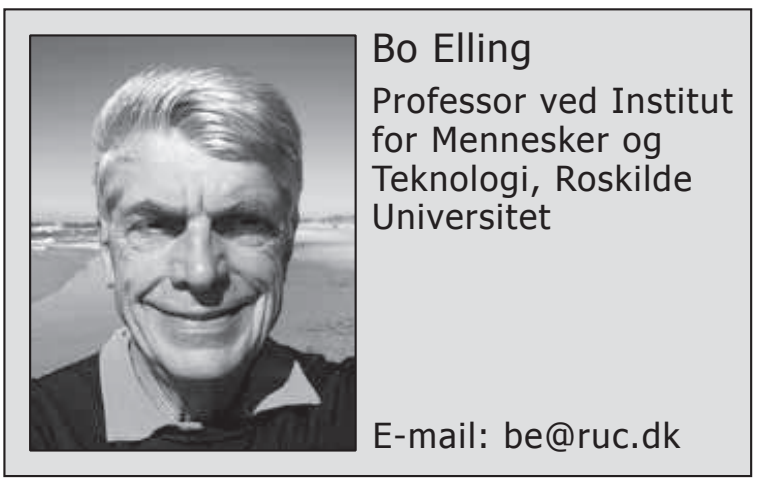

et planlægningsbegreb, der tildeler borgernes deltagelse meget videre betydning og derfor også med en vis ret kan betegnes som en (udvidet) "kommunikativ planteori".

\section{Borgerdeltagelse, planparadigmer og kommunikativ planteori}

Den fysiske planlægning har altid skullet tilsikre fælles samfundsskabte værdier og behov. I de første årtier af det tyvende århundrede blev dette almindeligvis set synonymt med de statslige interesser og behov over for det individuelt private og markedsmæssige. I takt med at statens omfang og aktiviteter i efterkrigstidens højkonjunktur steg til ukendte højder, blev også opfattelsen af de fælles værdier og behov udfordret og spørgsmålssat. De var ikke længere så oplagt bare statslige og måtte i højere grad begrundes med konkrete argumenter. Samtidig blev staten en faktor i forskellige samfundsgruppers interessevaretagelse, hvilket nødvendiggjorde specifik begrundelse og prioritering af dens aktiviteter. Hvor planlægningen indtil da havde været anset for et eksklusivt ekspertanliggende, blev borgerdeltagelsen og argumentationen bag nye tiltag bragt ind i processen. Debat og argument blev nøglebegreber (Se f.eks. Fisher og Forester 1993). Planlægning måtte ses som et offentligt anliggende, der gennem deliberative processer tilvejebragte argumenter for et fælles bedste (f.eks. Dryzek 1992, Miller 1992). Argumentet kunne baseres på almindelige (læg-)menneskers synspunkter og værdier, ligestillet med eller stillet over eksperternes indsigter og erfaringer. Der taltes om "local knowledge" eller kontekstuel viden i betydningen konkret eller stedlig modsat generaliserede eller abstrakte vidensformer. Fisher argumenterede for, at offentlig planlægning for at være effektiv eller bare virksom måtte forbindes til borgernes konkrete viden og indsigter (Fischer 2000). Men hermed såede han også tvivl om borgerdeltagelsens tilsigtede effekt, der åbenbart ikke principielt var ment som en aktiv medvirken i planlægningens tilblivelsesfase, men et led i realiseringen af planlæggernes og de politiske beslutningstageres initiativer og hensigter.

Andre så borgerdeltagelsen som en social læringsproces, hvori aktørerne opnåede erfaringer, som kunne formidle andre kollektive tiltag og dermed 
skabe fornyelse, omfordeling af magt, delagtighed og ansvarliggørelse (Nielsen og Nielsen 2007:24-34, Dryzek 1997:133-143, 1998-199, Becker-Schmidt og Knapp), men hvor altså effekten af borgerdeltagelsen primært er noget uden for processen; noget "ved siden af" eller "efterfølgende" (social læring).

Heroverfor lå en direkte fokusering på selve planprocessen i den tilgang, som kaldes empowerment (Andersen 2007), dvs. magtliggørelse af bestemte grupper for derved at gøre dem i stand til at hævde deres interesser bedre i forhold til andre magtgrupperinger. Umiddelbart forekommer det sympatisk at gå direkte til sagen, men empowermenttilgangens manglende begrebsliggørelse af planlægningens indhold indebærer også en fare for, at den mister orientering og får svært ved at forholde sig til de samfundsmæssige vilkår, som planlægning i den globale tidsalder må indskrives i. Det kunne siges således: magtliggørelse i forhold til hvem og hvad? Og hvorfor?

Allerede Fischer (2000) havde påpeget, at borgerdeltagelsen ville være særligt afgørende inden for miljøregulering og -planlægning. Inden da havde Rio Deklarationen (1992) og den efterfølgende Aarhuskonvention (1998) understreget, at borgerdeltagelse måtte være en afgørende parameter i samfundenes omstilling til bæredygtighed. Aarhuskonventionen satte borgerdeltagelsen som en rettighed $\mathrm{i}$ alle miljøpolitiske beslutninger og understregede dermed samtidigt, at det repræsentative demokrati på miljøområdet måtte suppleres med et mere direkte demokrati gennem borgerdeltagelse i planlægnings- og beslutningsprocesser. Også den efterfølgende omfattende diskussion om governance trængte ind i planlægningslitteraturen og understregede betydningen af deltagelse og interessenters medvirken i planprocessen og de fordele, der herved kunne opnås demokratisk og indholdsmæssigt (Gualini 2010, Verma 2010).

Imidlertid formår disse governance-tilgange ikke at overskride deres karakter af interessevaretagelse og de etablerede magtgrupperingers dominans i planlægnings- og beslutningsprocesserne, der netop har været den almene begrundelse for borgerdeltagelsens nødvendighed og det etablerede lovgrundlag herfor. Som Gualini (2010) har påpeget, er governance-begrebet et ikke særlig vellykket forsøg på at imødegå den moderne velfærdsstats styrings- og legitimitetsproblemer. Det repræsenterer snarere en tilbageskuen på statslig styring som udtryk for en "offentlighedens interesse" - også af lokal karakter - varetaget gennem forhandling mellem interessenter.

Nærværende artikel vil derfor besvare spørgsmålet: Hvordan kan borgerdeltagelse i planlægningen medvirke til at skabe nye magtformer, der kan udfordre samfundenes ændrede magtforhold i globaliseringens tidsalder? Her tænkes især på den verdensomspændende kapitalismes stigende dominans også på de lokale miljømæssige forhold og bestræbelser på bæredygtighed. Den udfordring har det politiske system alene vist sig ude af stand til at varetage (Stanton 2014:49). Artiklen argumenterer derfor for en direkte involvering af borgerne, især på områder hvor planlægningen nødvendigvis 
må baseres på værdier og prioriteringer, og hvor på forhånd givne interesser kommer til udtryk i ujævne magtforhold, eksempelvis dominerende investorinteresser. Begge dele er karakteristiske for den fysiske planlægning og især by- og miljøplanlægningen, som her er i fokus.

\section{Planparadigmer}

Opfattelsen af borgerinddragelsens nødvendighed og af magt i planlægningen karakteriserer tre meget forskellige paradigmer inden for planlægningsteori. Disse skal kort opridses for at klargøre udgangspunktet for diskussionen af borgernes rolle i skabelsen af nye magtformer.

Det rationalistiske paradigme (Friedmann 1987:51-179, Lindblom 2003) ser planlægningsprocessen som en ekspertstyret målorienteret proces. Eksperterne anses for at være bedst i stand til, ikke blot at definere de ønskbare mål $i$ en given situation, men også til at udvælge de midler, der sikrer processens rationalitet - altså opnåelsen af målene på den mest effektive måde. Magten og kontrollen med processen udøves i rationalitetens (fornuftens) og videnskabens navn og fremstår dermed som neutral eller objektiv. Der udøves ikke magt, men blot rationalitet.

Det inkrementelle paradigme (Lindblom 2003) opstiller planlægningens målsætninger ud fra tidligere erfaringer og praktiske muligheder for deres opfyldelse. Det har et stærkt skær af realisme contra det rationalistiske paradigmes idealisme. Den amerikanske planlægningsteoretiker Charles Lindblom (2003) kalder det en "science of muddling through". Det handler ikke om hvad der er godt at opnå, men hvad der er muligt i en aktuel situation. En god plan er en, der er enighed om. Paradigmet fordrer et stærkt element af forhandling mellem interessenterne, og det betegnes ofte forhandlingsplanlægning. Selv om det fremstår som et møde mellem ligeværdige parter, er magt og interesser afgørende i sådanne forhandlinger. Magten optræder forklædt som forhandling.

Det deltagerorienterede paradigme (jf. referencerne nedenfor) har til forskel fra de to først-nævnte fokus på borgernes inddragelse og deltagelse. Trukket skarpt op, foreskriver paradigmet identifikation af kollektive værdier og mål i dialog med borgerne på trods af eksperters (mere) ideale forestilling om et gode og på trods af stærke aktørers interessevaretagelse. I et magtperspektiv kan borgerdeltagelsen udtrykke både forskellige former for og grader af magt, og det handler det følgende om. Især om at begrunde den magt, der bør tillægges borgerdeltagelsen.

\section{Borgerdeltagelse og magt i det deltagerorienterede planparadigme}

De deltagerorienterede planteorier ser imidlertid meget forskelligt på, hvorfor borgerne må inddrages og på magt i planlægningen.

Fischer og Forester sigter på sprogets betydning i inddragelsesprocessen og anser det som en ressource, der kan bidrage til formning af omverdenen 
og ikke blot som et redskab til at genfortælle det eksisterende (Forester 1989, Fischer og Forester 1993). Magten ligger i sproget, som må gives mulighed for udfoldelse.

Healey (1996) ser den brede borgerinddragelse som en mulighed for at hæmme enkeltinteresser eller magteliter. Magt er oftest tilknyttet eliter eller enkeltstående interesser, og den brede borgerinddragelse forhindrer disse $\mathrm{i}$ at dominere planlægningen. Dette fokus på det fælles i det ytrede har også givet Healeys argumentative tilgang navnet collaboratory planning.

For Hoch (1996) og Hillier $(1998,2002)$ handler deltagelse om at udligne forskelle i magtpositioner og håndtere interessemodsætninger. Magten forstås som et modsætningsforhold, men også som en kreativ ressource. Magten kan skabe nye visioner, men må ikke kunne udøves eller domineres eksklusivt af særinteresser.

Innes og Booher ser inddragelsen af de forskellige interesser som en mulighed for gennem dialog og konsensus at skabe ny viden på tværs af interesser og magtpositioner (Innes 1998, Innes og Booher 1999, 2000). Planlægningsprocessen ses som en magtudjævnende proces.

Hvis governance-tilgangen til planlægning tages med i det deltagerorienterede paradigme - der formuleres i mange varianter - kan den forstås som en magtudjævnende proces, hvor hverken enkeltstående myndigheder, eksperter eller interesser gives forrang. Hierarkisk magtstyring er således udeladt og erstattet af samarbejdende netværk (Hillier 2010).

Alle de nævnte teoretiske positioner knytter altså borgerdeltagelsen til magt. Enten som en magtudligning eller en svækkelse af dominerende magt eller som en magtudøvelse i sig selv, der skaber en fælles videnssfære. I det sidstnævnte tilfælde ses magten som formet demokratisk.

På dette grundlag tildeles borgerdeltagelsen to mulige roller, hvor planprocessen ikke blot ses ud fra en analytisk vinkel, men også fra en praksisvinkel. Den kan ses som en magtudjævnende proces i sig selv. Men som led i en planlægningspraksis kan den også ses som en for planlæggerne og de politiske beslutningstagere hensigtsmæssig legitimeringsform under vanskelige vilkår. Inddragelsen betyder, at meget forskellige befolkningsgrupper, enkeltstående borgere, investorer og institutioner oplever det som deres legitime ret at varetage deres specifikke interesser og gør det dermed rigtig svært at træffe en beslutning, der kan opnå tilstrækkelig bred politisk legitimitet. Det kan derfor være fristende at holde tilsyneladende åbne fora for diskussion og forslag og så - reelt - gennem et kontrolleret udspil forsøge at styre diskussionen, samt, når alle har fået lejlighed til at ytre sig, træffe "en nødvendig" beslutning. En beslutning, der som oftest afspejler andre realiteter og magtforhold end ligelig fordeling af lydhørhed over for de mange, der ytrer sig. Realiteterne og magten forbliver imidlertid ubelyst .

Det må derfor siges at være et paradoks i alle de nævnte tilgange, at de stopper analysen ved den sproglige manifestation af interesser eller ved selve 
dialogen herom, hvorimod vilkårene, hvorunder beslutningen efterfølgende faktisk tages, ikke analyseres.

Nedenfor skal problematikken belyses specifikt ud fra Patsy Healey's collaboratory planning. Hun er især interessant, fordi den manglende analyse af magtforholdene kobles sammen med hendes anvendelse af Habermas' begreb om kommunikativ rationalitet. Kritikken af Healey er således ment som et korrektiv, der kan bidrage til den videre fremstilling af et planbegreb og en kommunikativ planteori ud fra en habermasiansk teori om kommunikativ handlen. Men i forhold til Healey også supplerende med begrebet om kommunikativ magt.

\section{Deltagelse og magt i Patsy Healey's Collaboratory Planning}

Patsy Healeys collaborative planlægning indskriver hun i én kort sætning: "we choose action after debate" (Healey 1996). Hermed afskriver hun eksplicit det rationalistiske såvel som det inkrementelle planparadigme. Det førstnævnte bygger på a priori værdier ("the substantive route"), og det sidstnævnte bygger i realiteten på de værdier, der erfaringsmæssigt kan "overleve" magtkampe og interessemodsætninger - altså også eksisterende værdisæt. Healey ønsker en planlægning, som bygger på "the process route", og som viser vej ud af relativismens dilemmaer, som jo i den inkrementelle planlægning løses ved magt. Rationalismens logiske begrundelser (reasoning), der er baseret på videnskabeligt konstrueret viden, vil hun erstatte med Habermas' begreb om kommunikativ rationalitet baseret på intersubjektiv gensidig forståelse. Collaborativ planlægning er en fælles vilje til at afveje indbyrdes forbundne, men ofte modstridende formål og til at opnå konsensus om bestemte udviklingstiltag identificeret gennem kollektiv bestræbelse. Hertil fremstiller Healey et regelsæt på 10 punkter baseret på Habermas' diskursetik (Habermas 1996b), der understreger den gensidige respekt mellem de deltagende, refleksiviteten i dialogen, det kollektive frem for det individuelle, at etiske kriterier og æstetiske erfaringer kan være grundlag for handling og ikke bare f.eks. økonomiske gevinster eller tekniske fordele, og at magt ikke må være noget givet, men etableres kollektivt i processen (Healey 1996:247-249).

Healeys intentioner kan ses som sympatiske og demokratiske, men hun er nærmest idealistisk i sin forståelse af borgerinddragelsens udjævning af magteliter og etablering af kollektive goder gennem diskursiv argumentation. Hvordan enkeltindividers eller gruppers vilje til noget kan opsummeres til samfundsmæssig magt og under hvilke forhold, den kan etableres, forbliver et spørgsmål om gode viljer og respektfuld optræden af myndigheder og deltagende.

Min kritik af Healey på tre punkter, har betydning for det følgende. For det første læser Healey teorien om den kommunikative handlen som en konsensusteori. Via etablering af herredømmefri rum for dialog kan der skabes kommunikativ fornuft frem for den ensidigt kognitivt-instrumentelle. Kom- 
munikativ rationalitet er imidlertid en samfundsmæssig realitet. Den er uddifferentieret historisk i den samfundsmæssige dynamik og ikke etableret under bestemte forudsætninger eller antagelser. Men i den samme dynamik udsættes den for stærk dominans af teknisk og økonomisk rationalitet. Aktuelt er de etiske og æstetiske rationalitetsformer vanskeligt identificerbare, og det er deres virke i samfundet derfor også (Elling 2003:111-149, 213-216, 237-242, Elling 2007:341-346, Elling 2013a:160). En teori om kommunikativ planlægning må kunne anvise, hvordan disse rationalitetsformer gøres virksomme i planlægningsprocessen. Healeys "besværgelser" og hendes antagelse af muligheden for magtfri rum er ikke blot en selvmodsigelse i forhold til eksistensen af magteliter, som må nivelleres, men helt utilstrækkelig.

For det andet forstår Healey menneskelig handlen som et resultat af individuelle valg, af personlige værdier og holdninger, af et personligt rationelt valg. Men som det vises nedenfor er menneskelige handlinger som udgangspunkt resultat af samfundsmæssige strukturer; det er systemiske sammenhænge, der påtvinger individer bestemte handleformer, og i disse sammenhænge indgår også magtrelationer. Også menneskenes forståelse, kropslige og følelsesmæssige oplevelse af omverdenen er dannet socialt. Sproget og de øvrige kommunikative aspekter er af intersubjektiv karakter, der altså aktiverer vores forståelsesformer, værdier og opfattelser af samfundsmæssige fænomener i sociale relationer. Teorien må kunne identificere disse strukturer og deres påvirkning af handlen.

For det tredje kommer Healey til at skjule magten, da hun ikke forholder sig til, hvordan den magtudjævning, som hun taler for er nødvendig, skal eller kan foregå. Den magt, der alligevel er der, forbliver skjult. Mere naivt, tror hun måske, der kan tages beslutninger uafhængigt af magten, hvis man bare har identificeret "det bedste" og argumenteret herfor.

I det følgende skal jeg forsøge at anvise en vej til nivellering af magteliter, hvor borgerdeltagelsen ikke bare bliver en legitimeringsmekanisme for skjult magtudøvelse, men i sig selv kan gøres til en magtfaktor - en myndiggørelse realiseret som modmagt. Det vil være en teori om kommunikativ planlægning fortolket ud fra Habermas' begreber om kommunikativ handlen og kommunikativ magt. Begreberne gør det muligt at sammenknytte planlægningsteorien med samfundsteorien. Dermed kan planlægningens forskellige faser og nødvendigheder, herunder borgerinddragelsen, knyttes sammen med samfundsstrukturen og de rammer og vilkår, den sætter for planlægningsprocessen, og dens beslutningsformer. Teorien hævder endvidere, at der netop herved kan opnås bæredygtighed og langsigtethed i by- og miljøplanlægningen, som i de eksisterende magteliters herredømme ikke er mulig. Først og fremmest fordi de sidstnævnte kun formår at handle med effektivitetens rationalitet og ikke evner at inddrage de etiske og æstetiske rationalitetsformer, der er så afgørende for det bæredygtige og langsigtede inden for dette planområde. 


\section{Planbegrebet i fortolkning af kommunikativ handlen - handlekoordinering}

Habermas' teori om den kommunikative handlen er en teori om det moderne samfund, dets handlingsformende strukturer og de øvrige forhold, der ligger til grund for menneskers handlen i samfundet. Handlinger er, afhængigt af deres kontekst, enten mål- eller forståelsesorienterede, og deres effekt eller succes vurderes på grundlag af forskellige former for fornuft, som ikke bare kan vælges af den handlende selv, men er normativt givet i den specifikke kontekst, der således optræder som et strukturelt vilkår.

Konteksten kan i teorien om den kommunikative handlen enten være system eller livsverden, som tilsammen udgør samfundet på en og samme tid (Habermas 1996a:281-282). Systemet har to subsystemer: erhvervssystemet markedet - og det administrative system - statsapparatet, der i moderne samfund er uddifferentieret som særlige kontekster for handling med et specifikt formål (Ibid.:409-410). Til den systemiske kontekst knyttes rationalitetsformen kognitiv-instrumentel rationalitet, da en handlings orientering inden for denne kontekst altid er forhåndsbestemt af et givet mål eller formål (Ibid.:136, 265). For markedet er det givne formål profitten, og for statsapparatet et det maksimal legitimitet. Den kognitivt-instrumentelle rationalitets gyldighedsfordring er effektivitet - $\mathrm{i}$ hvilken udstrækning de handlende opnår det på forhånd givne formål. Handlinger inden for systemet koordineres kommunikativt, men i det moderne samfund er denne kommunikation så udviklet (effektiviseret), at den sproglige koordinering helt er erstattet af medier for kommunikation: henholdsvis mediet penge inden for markedet og mediet magt inden for statsapparatet (Ibid.:438).

Hertil kommer, at der i det moderne samfund dannes (uddifferentieres) ekspertkulturerne: videnskab, moral og kunst, der hver især rendyrker handlinger med hver sin gyldighedsfordring på rationalitet (Ibid.:424). Det er gyldighedsfordringerne: sandhed, rigtighed og ment som ytret med henholdsvis kognitiv-instrumentel (sandhed/viden), moralsk-praktisk (det gode) og æstetisk-ekspressiv (det skønne) rationalitet (Ibid.:265-267). Som vi skal se nedenfor, er det særlige ved ekspertkulturernes rationalitet, at de ved nyttiggørelse i den systemiske kontekst instrumentaliseres (målorienteres), hvorimod de kan opretholde deres egentlige form ved en nyttiggørelse inden for livsverdenen.

Livsverdenen består først og fremmest af det sociale liv, socialiseringen af nye samfundsindivider og de kulturelle overleveringer; altså kontekster der ikke er systemliggjorte (Ibid.:308). I livsverdenen er handlingers formål ikke forudgivne, men bestemt af de enkelte handlende individer selv eller af fælles accepterede normer under konstant udvikling eller forandring og altid bestemt af menneskenes gensidige forståelse. Herunder de kulturelle overleveringers normer og værdier fra tidligere samfundsformer, som nulevende samfundsindivider med deres frie viljer påtager sig. Love er normsæt ophøjet til almen gyldighed gennem de politisk-demokratiske beslutningspro- 
cedurer og kan selvfølgelig ikke umiddelbart forkastes eller fravælges, men må efterleves af alle samfundsindividerne. Handlinger vurderes i livsverdenen i forhold til kommunikativ rationalitet, som indeholder alle de ovenfor tre nævnte aspekter af rationaliteten i en ikke-uddifferentieret form (Ibid.:126). For den enkelte handling kan der godt lægges vægt på forskellige aspekter af den kommunikative rationalitet, eksempelvis en moralsk-praktisk norm eller noget kognitivt instrumentelt, frem for alle rationalitetens aspekter på en og samme tid. Det er de handlende selv, der afgør hvilket aspekt, der lægges til grund - det er ikke givet udefra på forhånd, som det er tilfældet i systemiske sammenhænge.

Når handlinger koordineres efter forskellige kriterier i de forskellige kontekster, og deres effekt ses i forhold til forskellige former for rationalitet, vil relationerne mellem disse kontekster være afgørende for samfundets samlede udvikling, da der kan være modstridende kriterier og rationaliteter i disse relationer. Teorien om den kommunikative handlen er således også en teori om samfundets dynamik, om hvilke systematisk bestemmelige relationer, der i det moderne samfund opstår mellem system og livsverdenen. Habermas bestemmer tre udviklingstendenser og formulerer dem i tre teser. Den forste tese er, at der sker en afkobling mellem system og livsverden (Ibid.:352). Afstanden mellem de to former for handlekoordinering bliver stadig større og dermed bliver det stadigt sværere at få livsverden og systemer til at virke sammen. Den anden tese er, at systemet $i$ stigende grad koloniserer livsverdenen (Ibid.:382, 438). At både markedet og statsapparatet i stigende grad påvirker livsformerne i livsverdenen med deres systemiske logikker. Livsverdenen påtvinges handleformer, som egentlig ikke passer til eller stemmer overens med dens egne kriterier for handling og rationalitet. Endelig er den tredje tese, at livsverdenen forarmes kulturelt, idet mere og mere af livsverdenens liv og handleformer uddifferentieres (dvs. specialiseres) til/i ekspertkulturerne, hvorfra deres indsigter ikke vender tilbage til livsverdenen, som derved forarmes (Ibid.:419-420).

Tilsammen tegner disse teser et spændingsfelt mellem system og livsverden, hvor de forskellige handlekoordineringer og kriterier for vurdering af handlingers effekt ikke harmonerer, men må kæmpe om dominans. Det er $i$ dette spændingsfelt, at planlægningen foregår.

Det er også muligt, at bestemme en koordinationsform for planlægningshandlinger til sammenligning med koordinationsformerne bestemt for handlinger inden for henholdsvis markedet, statsapparatet, ekspertkulturerne og livsverdenen. Koordinationen for planlægningshandlinger må nemlig optage elementer fra alle de øvrige koordinationsformer og forsøge at nyttiggøre dem på tværs, dvs. både i kraft af og på trods af disses forskellighed og reservation til bestemte kontekster eller sammenhænge som eksempelvis markedet eller dele af livsverdenen. Planlægning kan således ses som en aktivitet, som anvender flere forskellige handlekoordineringsformer på en og samme 
tid, uanset deres egentlige bestemmelse eller hensigt. Derved bringes mange aktører sammen på samme tid og med hver deres sæt af formål, eller ikke-formål, for handlingen og med hver deres sæt af kriterier for, hvad handlingens tilsigtede effekt skal være. Når der endvidere i et sådant mix ikke eksisterer et overordnet styringsmedie, men kun elementerne af de enkelte kontekstuelle medier, så giver det sig selv, at planhandlingen må styres på en anden måde og ikke kan være et resultat af nogen enkeltstående aktørs hensigt. Den må netop ses som konstitueret af mange forskellige interesser og hensigter og bør derfor ikke ses som noget, der kan forudses ved indgangen til planlægningsprocessen, men må netop opfattes som et ukendt mål, der udkrystalliseres $\mathrm{i}$ selve processen og altså realiseres i varierende og uforudsigelig grad.

I politik er mediet for handlekoordinering magt. På markedet er mediet for handlekoordinering penge. Men penge bliver i sig selv ved anvendelse inden for planlægning til en magtfaktor, der kan gennemtvinge både målsætninger og styring, som ellers ikke ville være muligt på grund af manglen på selvstændiggjorte medier, som virker uafhængigt af de handlende. Heri ligger også den afgørende forskel på planlægning og politik, selv om planlægning i en bestemt forstand selvfølgelig er en politisk handling. Planlægning må anvende både viden og midlerne (til forskel fra medierne) penge og magt uden en overordnet på forhånd givet handlekoordineringsmekanisme, men er netop $i$ sig selv en sådan handlekoordinerende mekanisme. Planlægning er ikke selvstændiggjort og kan således ikke forlade sig på mediemæssig styring eller koordinering, men må være en bevidst villet menneskelig styret aktivitet.

Hermed er imidlertid kun selve formen for planlægning udfoldet. Tilbage står bestemmelsen af selve magtudøvelsen, som denne form giver mulighed for. Den kommunikative planlægnings magtbegreb må fremstilles. Som vi har set, er det netop denne bestemmelse, som Healey og de øvrige deltagerorienterede planteorier mangler.

\section{En kommunikativ planlægning ud fra teorien om kommu- nikativ handlen og magt}

\section{Planlægningens aktører og deres handleformer}

Når samfundet ses som både livsverden og system på en og samme tid, hvortil knyttes forskellige handle- og rationalitetsformer, må de handlende i en planlægningsproces - planlægningens aktører - forstås derudfra. De handler i bestemte handlekoordinerende kontekster, og deres handling er struktureret/ikke-struktureret af disse kontekster med tilhørende rationalitetsformer. Aktørerne kan principielt inddeles i fire grupper: forvalterne, borgerne, bygherren/investorerne og eksperterne.

De planlæggende myndigheder - forvalterne $e^{1}$ - er de politisk valgte beslutningstagere og deres embedsmænd, der som planlægnings-eksperter står til rådighed for dem. De tilrettelægger planlægningen og forvalter det regelsæt af forordninger, planlægningen skal udføres i forhold til, for eksempel planlo- 
ven. Forvalterne indgår i en systemisk handlekoordinering via mediet magt, og de argumenterer således resultatorienteret og anvender ekspertkulturerne i en sådan sammenhæng til at fremme deres ønskede resultater. De instrumentaliserer ${ }^{2}$ eller koloniserer ekspertviden. De er således også underlagt et systemisk imperativ om opnåelse af maksimal legitimitet i deres handlinger/ beslutninger, som sigter på kognitiv-instrumentel rationalitet.

De berørte i bred forstand - borgerne - er både dem, planlægningen udføres for eller af hensyn til, som planlægningen kan have konsekvenser for, og som dermed kan have forskellige motiver til at deltage eller involvere sig $\mathrm{i}$ planlægningen. Borgerne indgår i en sproglig handlekoordinering via offentlighedens medier med afsæt i livsverdenen. De argumenterer således forståelsesorienteret og anvender ekspertkulturerne i en kommunikativ handleform med tilsvarende kommunikativ rationalitet.

En tredje gruppe af rolleindehavere er investorerne eller bygherren(erne $)^{3}$, da planprocessen ofte er forbundet med en konkret investering i nye faciliteter, anlæg, veje, produktionsanlæg, bydele, energianlæg, infrastruktur og meget andet privat eller offentligt. Investorerne indgår i en systemisk handlekoordinering via mediet penge, argumenterer resultatorienteret og anvender ekspertkulturerne til at fremme deres ønskede resultat. De instrumentaliserer eller koloniserer ekspertviden, og profitten er deres systemiske imperativ, som er styret af kognitiv-instrumentel rationalitet. Deres handlen kan således også karakteriseres som strategisk, dvs. forfølgende et systemisk givent mål, ofte på bekostning af de øvrige aktører.

Endelig er eksperterne en fjerde gruppe, der besidder viden og erfaring inden for det pågældende område og som fungerer som rådgivere for en af de tre førstnævnte grupper af aktører, der kan kaldes planlægningens hovedaktører. Selv om førstnævnte og tredje gruppe kan være sammenfaldende, som når f.eks. offentlige myndigheder samtidigt optræder i rollen som bygherrer eller investorer, ændrer denne dobbeltrolle ikke på, at der må skelnes mellem forvaltere og eksperter. Forvalterne er planlægningseksperter ansat af det politiske system. Som eksperter må de indrette deres handlinger, råd og anvisninger på, at de politiske beslutningstagere handler i det politiske system, inden for dettes imperativer og således i deres beslutninger søge mod systemets målsætning: maksimal legitimitet i magtanvendelsen. Forvalternes ekspertise må underordne sig denne målsætning, dette imperativ, og derigennem instrumentaliseres deres tænkning og målsætning til de systemiske behov. Det gælder også for andre eksperter tilknyttet planprocessen, men her er det igen afgørende i hvilken handlekoordinerende sammenhæng, de er involveret i processen. Er det som systemiske aktører eller livsverdenens? I førstnævnte tilfælde instrumentaliseres deres ekspertise til det målorienterede. I sidstnævnte er ekspertisens anvendelse ikke instrumentaliseret på forhånd. Eksperten deltager i planprocessen som borger, som det der kunne betegnes som kvalificeret borger. Dem er der mange af med det til fælles, at de bruger 
deres ekspertise i den gensidige forståelsesproces med sigte på kommunikativ rationalitet.

Aktørerne spiller således roller, der alle skal bidrage med input til en endelig plan. Indholdet er forskelligt i forhold til fra hvilken aktør, det stammer, og det er forskelligt med hensyn til dets imperative effekter for den beslutning, de planlæggende politiske beslutningstagere må træffe. Lad os se på indholdet af informationen først: hvem bringer den ind, hvad bringes ind og hvor kommer det fra? Lad os derefter se på imperativet om den maksimale legitimitet, som de i sidste instans besluttende og ansvarlige myndigheder er underlagt: hvordan forandres selve magtformen i den kommunikative planproces?

\section{Borgerne og den kommunikative rationalitet}

Borgerne er de eneste, hvis rolle i planprocessen ikke er konstitueret af en formålsbestemt handlekoordinerende kontekst, men som kan forholde sig frit og forståelsesorienteret til processens målsætninger. Den information, som alle andre aktører sender i planprocessen, vil altid være subsumeret disse aktørers primære, forhåndsbestemte formål. Det omfatter etiske og æstetiske ytringer, som altid vil være fremsat under hensyn til de overordnede formål med at agere i planprocessen. En bygherre vil kunne anvende etiske argumenter for realiseringen af sit projekt eller sin plan, eksempelvis dets eller dens miljømæssige fortrin. Men hvis sådanne fortrin fremhæves, for at fremme projektets eller planens gennemførelse, ændrer de karakter. De instrumentaliseres, når de anvendes som argumentation for opnåelsen af et givet systemisk formål. Også inden for en livsverdensmæssig kontekst kan ekspertviden anvendes med henblik på et bestemt mål. Forskellen til den systemiske instrumentalisering er den helt afgørende, at i livsverdenen er denne formålsorientering frivillig eller villet - den er ikke nødvendiggjort på forhånd eller strukturelt givet. Den er ikke tvangsmæssig, men resultat af den handlendes frie valg. En borger kan eksempelvis argumentere for nødvendigheden af et nyt kraftværks miljømæssige fortrin, uden at det kan påstås, at borgeren ønsker dette for økonomisk vindings skyld.

Konklusionen er, at viden, information og argumentation med et etisk eller æstetisk rationale, som ikke kan reduceres til kognitiv-instrumentel rationalitet, kun kan bringes ind i planprocessen af borgerne. Enten gennem borgernes handlen med tilknyttet kommunikativ rationalitet, eller ved at borgere handler direkte inden for et etisk eller et æstetisk rationalitetskompleks. Eksperter inden for et af ekspertsystemerne kan også bringe deres respektive ekspertviden ind med reference til systemets eget rationalitetskompleks. Men når dette er etisk eller æstetisk, må det ske ved, at eksperterne agerer som borgere. Dvs. at de ikke optræder professionelt engageret af enten bygherrer eller forvaltere, for i så fald vil deres viden som eksperter instrumentaliseres, fordi den derved tilknyttes en kognitiv-instrumentel rationalitet. (Elling 2003:350, 336-350). 
Dette er nok så radikalt, da det er ensbetydende med, at etisk og æstetisk viden i en ikke-instrumentaliseret form kun bringes ind i en deltagerorienteret planproces, hvorimod en rationalistisk og en inkrementel planproces ikke tilføres en sådan viden. Forudsætningen er, at den borgerdeltagende planproces muliggør, at disse vidensformer kan gøres gældende ved, at planprocessen ikke på forhånd er kontrolleret af enten de forvaltende myndigheder eller bygherren. Processen skal med andre ord muliggøre borgernes deontologiske 4 argumentation for at kunne betegnes som en kommunikativ planproces i fortolkningen her, dvs. for at det, som Habermas kalder kommunikativ magt, ${ }^{5}$ kan gøre sig gældende. Heri adskiller den sig også radikalt fra andre fortolkninger af det deltagerorienterede planparadigme, der ikke forudsætter en sådan præcisering.

\section{Borgerne og den kommunikative magt}

Habermas skelner i sit senere demokratiteoretiske hovedværk Faktizität und Geltung mellem forskellige former for magt og indflydelse inden for en demokratisk retsstat (Habermas 1998:166-207). Det afgørende i hans demokratiopfattelse er, at magten ikke kan legitimere sig selv, men at det må ske via det diskursive niveau i den politiske offentlighed. Magten inddeler han i tre niveauer: politisk indflydelse, som dannes i den ikke-institutionaliserede meningsdannende offentlighed, kommunikativ magt, som skabes i institutionaliserede diskursive beslutningsprocesser og administrativ magt, som selve magtudøvelsen i forvaltningsapparatet (Gregersen 1996:17). Eriksen og Weigård (2003:256-260) kalder disse stadier i genereringen af magt for henholdsvis social, kommunikativ og administrativ magt. Magtdannelsen sker altså i de sociale og politiske processer i offentligheden, og kun selve kanaliseringen af magten ind i parlamentet til en endelig politisk beslutning "reserverer" magtdannelsen til det politiske system.

Som vi har set ovenfor, udgøres handlekoordineringens princip i det demokratiske politiske system af magten og magtens bevarelse. Politisk magt skal legitimeres i kraft af dens udøvelse - ellers mistes den (Habermas 1996a: 364-365, Gregersen 1996:17, Elling 2003:366-368). Afgørende for en politisk beslutnings indhold er altså i sidste instans ikke, om den er f.eks. god eller dårlig, men alene om den kan vinde legitimitet i den befolkning, den vedrører, og i hvor høj grad en sådan legitimitet kan opnås. Det er hverken et moralsk eller et funktionelt spørgsmål. ${ }^{6}$ Det udelukker selvfølgelig ikke, at der kan være en forbindelse mellem en beslutnings saglige indhold og konsekvenser og så graden af legitimitet, den kan opnå. Med vægten på procedurer for både dannelsen af rationalitet og politisk demokrati sigter Habermas faktisk på at skabe muligheder for en sådan indholdsmæssig sammenhæng (jf. Eriksen og Weigård 2003:24). Selv om dette ikke vil være til videre diskussion her, er det klart, at sådanne procedurelle forhold kan være medvirkende til at give borgerne indflydelse og magt i den specifikke og konkrete udformning af en kommunikativ planproces. 
Kommunikativ planlægning i nærværende artikel fokuserer på, at der via en aktiv borgerdeltagelse kan ske en dannelse af kommunikativ magt i selve den borgerinddragende offentlighed, men også at den kommunikative magt skal bekræftes i en politisk beslutning af den planlæggende myndighed (typisk kommunalbestyrelsen). Denne myndighed må dermed tage ansvaret for beslutningen og dens mulige legitimering af magtudøvelsen. Det er altså ikke sådan, at forvaltningsapparatet blot omsætter en eventuelt opstået konsensus eller majoritet i borgerdeltagelsen til administrativ, planlæggende magt.

De politisk valgte myndigheder, eksempelvis kommunalbestyrelsen, må altså træffe en afgørelse, der kan opnå optimal legitimitet i offentligheden og blandt borgerne. Har borgerne efter den offentlige dialog i planprocessen en fælles eller tilnærmelsesvis fælles opfattelse af, hvad der må gøres - den bedste plan, det bedste projekt - vil det være let for myndighederne at tage en beslutning, som gives maksimal legitimitet. Er borgerne af meget forskellig opfattelse og ser meget afvigende løsninger, bliver det straks sværere for de besluttende myndigheder. Så kan den argumentation, der ledsager beslutningen, blive afgørende for, hvorvidt den kan opnå legitimitet i tilstrækkeligt omfang til, at de politiske beslutningstagere ikke straffes politisk på den ene eller anden måde.

Uanset hvad skal den politiske beslutning træffes! Den ansvarlige myndighed har både retten og pligten hertil - og til at tage ansvaret. Det kan ikke deles med offentligheden - det er omvendt netop over for offentligheden, at ansvaret må gøres gældende. Bygherren, hvis en sådan findes, må også tage en beslutning. Vil han investere i det pågældende projekt eller planen under de vilkår, som myndighedernes beslutning indebærer? Borgerne skal sådan set også tage en beslutning. Faktisk i to omgange og af en lidt anden karakter. De skal først give et endeligt indspil til den beslutning, som myndighederne må tage, og det kan være delt i mange forskellige indspil og af meget uens indhold. Det kan også afspejles som et samlet indspil, udtrykt i ét mandat, fordi de faktisk er enige. Dernæst skal borgerne forholde sig til den beslutning, som myndighederne endeligt vedtager. Vil de acceptere myndighedernes afgørelse, helt eller delvist? Vil de her og nu afvise den og forsøge at omgøre den gennem protester, aktioner, pression, fortsat offentlig debat? Eller vil de afvente næste valg og afsætte de pågældende beslutningstagere? Her kommer imperativet om magtens legitimitet ind og bekræfter ligeledes, at der må tages en beslutning, da legitimiteten ellers ikke kan opnås, men netop bliver til dens modsætning - altså mangel på legitimitet.

Den magt, som udøves i beslutningsprocessen, er altså dannet i den deltagende proces i hvert enkelt tilfælde som et resultatet af den handlekoordinering, der har fundet sted. Magten er med andre ord relativ, gestaltet af de specifikke planprocessers forløb og ikke givet på forhånd. Det er den magt, Habermas kalder kommunikativ magt. Derved er den forskellig fra ekspertmagten i det rationalistiske planparadigme og investormagten i det inkrementelle 
paradigme. Den er af langt mere kompleks og sammensat karakter. Samtidig med at den kan være svag i det enkelte tilfælde, kan den i andre have en langt større rækkevidde, fordi kompleksiteten rummer muligheder, som ikke kan være til stede, når magten er snævert og entydigt gestaltet i form af ekspertmagt eller investormagt. Muligheder som kommer af borgerdeltagelsen og den heraf følgende større transparens.

Et sådant magtbegreb med dets relationelle, midlertidige eller situationelle karakter kan samtidigt forklare, hvorfor deltagerorienteret planteori har en tendens til at anskue magt som noget nærmest forsvindende, som noget der erstattes af deliberative processer, også i de tilfælde hvor det erklærede formål med borgerdeltagelsen er at forhindre magteliters udfoldelse og dominans. Hvis magt betragtes som synonymt med deltagelse, uden at det ekspliciteres, hvordan den konkret etableres, og under hvilke betingelser den udøves, bliver den diffus og uvirksom. Det forbliver skjult, at magten overhovedet udøves og nødvendigvis må udøves, selv om den tilsyneladende "deles" med eller mellem de deltagende parter. Men problemstillingen må ses anderledes. Det handler ikke om at udradere magten eller gøre den uanvendelig. Det handler om at muliggøre en anden magt end den, der udspringer af ekspertise, kapital eller andre elitære former for hegemoni og dominans. Det handler om at gøre borgernes kommunikative magt eksplicit og virksom. I denne forståelse sættes der altså heller ikke lighedstegn mellem dannelsen af kommunikativ magt og det politiske ansvar for den endelige beslutning, sådan som deliberativ planlægningsteori har for vane, jf. Weersteg og Hajer (2010) som diskuterer denne forståelse af magt i deltagerorienteret planteori.

\section{Borgerne som modmagt og dens realisering i den kommu- nikative planlægning}

\section{Planlægning, borgerinddragelsen og dens ambivalens}

I det danske samfund er kommuner og staten politiske institutioner med demokratisk valgte beslutningsfora, som skal agere efter de ovenfor skitserede principper for handlekoordinering inden for de politiske systemer. De er også samtidig de primære planlæggende institutioner og beslutningstagere. Deres planlægning omfatter den fysiske planlægning, miljøplanlægning og andre planer med fysisk/rumlige konsekvenser. Siden den første Planlov fra 1973 har det været obligatorisk at inddrage borgerne i region, kommune- og lokalplanlægningen. I 1989 kom Vurdering af Virkningerne på Miljøet (VVM) og i 2004 Strategisk Miljøvurdering (SMV/MV) ind i billedet med obligatorisk borgerdeltagelse i henhold til EU-direktiverne 337/85/EØS og 42/2001/ EU. Aarhuskonventionen fra 1998 indførte nøjagtig samme krav og kriterier for borgerinddragelse i alle beslutninger vedrørende miljøet. ${ }^{7}$ Langt størsteparten og den vigtigste del af den fysisk-rumlige planlægning har altså i mere end 40 år været funderet $\mathrm{i}$ regelsæt $\mathrm{i}$ henhold til det deltagerorienterede planparadigme, og det legale krav herom er endog forstærket igennem årene. Det 
samme kan siges om de øvrige europæiske lande, Nordamerika, foruden en lang række lande i resten af verden, samt langt de fleste globale planlæggende institutioner som f.eks. FN, OECD, WTO, WBG. I alle disse tilfælde vil graden af legitimitet, som den politiske beslutning som planerne kan opnå, afhænge af borgerinddragelsen, den faktiske deltagelse, de konkrete forløb, som en planproces har været igennem, og selvfølgelig det konkrete resultat heraf, herunder hvilken betydning borgerne de facto tillægger den pågældende plan. Men maksimen om magtens legitimitet kan de planlæggende myndigheder principielt ikke omgå. Den forstærkes tværtimod af de formelle krav om borgerinddragelsen

Alligevel er det ikke svært at konstatere, ved en analyse af den faktuelle borgerinddragelse i planlægningen på kommunalt eller statsligt niveau, nationalt eller internationalt, at planlæggende myndigheder oftest har et dobbelttydigt forhold til borgerinddragelsen (Gregers 2013, Elling 2013b, Nielsen 2012, Hansen 2007, Elling 2003:15-25). På den ene side ses borgerinddragelsen som en legitimeringsfaktor, der kan muliggøre vanskelige beslutninger, - hvori legitime borgerinteresser ofte tilsidesættes - fordi et flertal af borgerne alligevel bakker op om planerne. Eller ved, at borgerne gives en blot tilsyneladende indflydelse på planlægningen. På den anden side ses borgerinddragelsen som besværlig, fuld af uforudsigeligheder og tidskrævende, uden at der kommer væsentlige resultater ud af den. De planlæggende myndigheder ønsker på én og samme tid borgerne inddraget som medvirkende legitimeringsfaktor, men kan ikke på forhånd kalkulere udfaldet og anskuer derfor i samme åndedrag borgerdeltagelsen som en usikkerhedsfaktor, der griber uhensigtsmæssigt ind i deres planlægning. Denne ambivalens medfører ofte mangel på helhjertet inddragelse, obstruktioner eller direkte forsøg på at kontrollere borgerinddragelsen, f.eks. ved at indsnævre problemstillingerne i den offentlige høring til noget, myndighederne kan kontrollere, overskue eller forudse (Nielsen 2012, Hansen 2007).

Nærværende artikel argumenterer for, at de planlæggende myndigheder herved begår en alvorlig fejl, fordi de derved overser den potentielle kraft, der ligger i borgerdeltagelsen, og som de oftest har brug for i langt højere grad, end de åbenbart selv lader til at ane. Man kan sige det sådan, at de planlæggende myndigheder i langt højere grad i de forløbne 40 år har lært sig at kontrollere og begrænse borgerdeltagelsen til opfyldelsen af deres egne umiddelbare behov, end at de har lært sig at give borgerne indflydelse på en måde, der kunne styrke samfundenes langsigtede planlægningsperspektiver i forhold til det pres, der i tiltagende grad kommer fra kortsigtede, økonomiske og sekteriske interesser bl.a. grundet globalisering og økonomisk internationalisering.

I det følgende skal problemerne omkring borgerdeltagelsen primært belyses ud fra det ovenfor skitserede magtbegreb i forhold til de radikalt ændrede vilkår for især fysisk planlægning, der igennem de seneste årtier er 
blevet resultatet af markedets tiltagende dominans. En sådan dominans ses lokalt-nationalt gennem enkeltinvestorers betydning for samfundenes økonomi og internationalt gennem globaliseringens altomfattende omdannelse af relationerne mellem nationerne og de overnationale forhold. En udtømmende beskrivelse og analyse af denne problematik er ikke mulig her. Det følgende skal blot illustrere, hvordan borgerdeltagelsens mulige gestaltning af nye magtforhold faktisk kan medvirke til at realisere essentielle planlægningstiltag - som markedets tiltagende dominans nationalt og internationalt både nødvendiggør og vanskeliggør. Det er det deltagerorienterede planparadigmes ultimative muligheder, der opridses, dels i forhold til nye planlægningsbehov og dels i forhold til den hidtil gældende praksis kommunalt, nationalt og internationalt, hvor borgerdeltagelsen altså primært er blevet set som et problem frem for et potentiale.

\section{Borgerne og planlægningens perspektiv}

Lokalt er situationen for kommunerne, at de er stærkt afhængige af enkeltinvestorers bidrag til den kommunale økonomi og velfærd, hvad angår f.eks. arbejdspladser/lønindkomst, vare-omsætning, kultur, branding, o.mm. De kommer derfor under stærkt pres for i deres planlægning at tilgodese sådanne investorers umiddelbare behov, selv om det oftest kun kan ske på bekostning af langsigtede og mere brede befolkningsmæssige interesser. Samtidig bliver nationalstaterne af globaliseringen og internationaliseringen tvunget til at tilpasse deres nationale politikker og planlægning til den internationale konkurrence og ligeledes i dette forhold prioritere umiddelbare behov og nødvendigheder på bekostning af langsigtede tiltag og omstillinger. Derved forstærker de desuden det beskrevne pres på de lokale/kommunale politiske myndigheder. De mere langsigtede problematikker, der er på spil, er eksempelvis klimatiltag og -omstillinger, langsigtet bæredygtighed i produktion og forbrug, ældreforsorg og børneomsorg i en befolkning, hvor disse segmenters vægt tiltager, uddannelse og kvalificering med langsigtede kriterier frem for kortsigtede behov og kompetencer, det fysiske miljøs og de kulturelle forholds kvaliteter og rekreative værdier i et langsigtet perspektiv kontra dets anvendelse umiddelbart til f.eks. økonomisk indtjening. Det er alt sammen situationer, hvor umiddelbare behov og muligheder strider mod mere langsigtede behov og vilkår, der må tilgodeses for at forhindre irreversible beskadigelser eller udviklinger, og hvor netop planlægning på langt sigt er afgørende frem for kortsigtede eller umiddelbare tilpasninger. Oven i købet kan det siges, at kommunerne i høj grad er de første til at mærke konsekvenserne af den manglende varetagelse af langsigtede behov, fordi det slår så direkte igennem på deres økonomiske formåen og de omkostninger, som eksempelvis klimaforandringerne presser ned over dem. ${ }^{8}$

Disse situationer stiller de politiske beslutningstagere og planlæggende myndigheder i alvorlige dilemmaer mellem på den ene side at tilgodese in- 
vestorers vilkår og umiddelbare behov og på den anden side behovet for at kunne legitimere deres beslutninger i den brede befolkning, som ofte vil stille sig stærkt kritisk over for sådanne investorinteresser/behov.

\section{Planlægning med kommunikativ rationalitet og magt}

Når borgerne er den eneste aktørgruppe, hvortil der kan knyttes et rationalitetsbegreb omfattende alle rationalitetens aspekter, vil borgerne også være den eneste aktørgruppe, der principielt eller i sidste instans vil være orienteret mod langsigtede og helhedsorienterede forhold i planlægningen. ${ }^{9}$ Alle andre aktører anvender en instrumentaliseret målsætning for en given beslutning, hvilket som regel er ensbetydende med varetagelsen af kortsigtede, umiddelbare og specifikke interesser; eksempelvis investorinteresser, selv om der undtagelsesvist kan findes eksempler, hvor det ikke er tilfældet.

Dette bør de planlæggende myndigheder være sig bevidst, når de udarbejder planer og igangsætter planlægningsprocesser. Ved at orientere deres planlægning mod borgernes interesser i bredest muligt omfang, kan de planlæggende myndigheder både fokusere på langsigtede perspektiver i planerne og desuden opnå legitimitet i deres beslutninger i videst muligt omfang. Dermed vil de ikke blot have en platform for at modstå pression fra investorgrupperinger, de vil faktisk også kunne træde i offensiven i forhold til disse interesser, hvis der via den offentlige dialog i planprocessen kan fremvises en bred borgertilslutning til mere langsigtede og helhedsorienterede plantiltag. De planlæggende myndigheder vil kunne skærpe deres krav til investorers indretning herpå og opnå en slags "double punch" - langsigtethed og alligevel investors aktivitet. Inden for eksempelvis kommunerne udspringer dette selvsagt af, at forholdet mellem kommune og investor er et magtforhold. Investor vil altid forsøge at få de nødvendige vilkår så billigt og fordelagtigt for sig selv som muligt. Men hvis kommunen kan fremvise en bred borgerlig alliance for bestemte løsninger, kan den lægge pres på investor og ikke omvendt.

Forudsætningen er logisk nok, at kommunen er bevidst om borgerdeltagelsens mulige potentiale og planlægger med sigte på bred borgertilslutning og samtidig er villig til at løbe de nævnte risici om processens og udfaldets uforudsigelighed. Selvfølgelig må kommunen også udøve den nødvendige opsøgende aktivitet med hensyn til at aktivere og interessere borgerne. ${ }^{10} \mathrm{I}$ forhold til de aktuelle tilstande må de planlæggende myndigheder ændre praksis og indse borgerdeltagelsens potentiale for langsigtet og f.eks. miljømæssigt robust planlægning frem for at se borgerdeltagelsen som en barriere for deres hensigter og mål. De må se borgerdeltagelsen som en proces, hvor der kan etableres kommunikativ magt, som en potentiel, og i princippet den eneste, modmag $t^{11}$ i forhold til dagens investormagt og dominans, der i længden kun giver de planlæggende og politiske myndigheder problemer og forhindrer realiseringen af nødvendige tiltag for omstilling og bæredygtighed. 
Modmagten er her kun skitseret på et meget abstrakt plan og i forhold til nogle få af disse års mest presserende problemstillinger inden for planlægningen. Hensigten er at fremstille hovedelementer af en deltagerorienteret planlægningsteori, der omfatter et andet magtbegreb i og med borgerdeltagelsen. Herunder den beslutningssituation, som planprocessen skal afsluttes med for at denne kommunikative magt kan gøres virksom. Den konkrete udformning af en deltagerorienteret planproces udfoldes ikke, kun dens begrebslige og principielle elementer. Men den er forhåbentligt konciperet tilstrækkeligt til at anskueliggøre forskellen til øvrig deltagerorienteret planteori og vise dens afgørende potentialer i forhold hertil.

Situationen rummer uden tvivl en meget alvorlig udfordring for de professionelle planlæggere, i det foregående kaldt forvalterne. For en sådan kommunikativ magt betyder jo, at deres professionelle kompetence kan risikere at blive tilsidesat af almindelige menneskers (måske) umiddelbare synspunkter og ideer, udelukkende i kraft af, at disse udgør et flertal. Uden at gå dybere ind i denne diskussion er det måske på sin plads her at minde om, at demokrati betyder flertalsstyre, og at flertallet består af individer, der alle er lige gode til at styre - uanset fødsel, uddannelse, rang, position, køn, alder, osv. I denne styreform bør flertallets afgørelse eller synspunkt betragtes som det bedste og det, som bør realiseres, fordi det udtrykker et gode uafhængigt af smag for magt, position, privilegier, besiddelser, alle former for særinteresser, god smag og dannelse, mm. ${ }^{12}$ Hertil kunne endvidere føjes, at hvis forvalterne havner i den situation, at et flertal af borgere ønsker noget andet end de, så kan det skyldes, at forvalterne selv ikke har været gode nok til at forklare borgerne, at de skal mene noget andet, eller det kan skyldes, at borgerne faktisk mener noget andet end forvalterne (jf. Elling 2003:363-366, 370).

\section{Konklusion}

Gængse deltagerorienterede planteorier formår ikke at gøre op med den blotte instrumentelle forståelse af rationalitet. De har gode intentioner om en anden planlægning, men disse indfries ikke på anden måde end ved et statement om, at borgerne skal spille med i processen. Deltagelse har været begrundet i behovet for demokratisering og i den lokale eller kontekstuelle inddragelse af viden, uden hvilken planlægningen mangler substans og realiserbarhed. Hvordan borgerinddragelsen reelt kan omforme planlægningen som proces, indhold og konsekvens har i høj grad manglet. Det er så forsøgt med nærværende fremstilling af en kommunikativ planteori.

Teorien er indsat $\mathrm{i}$ en ramme af forskellige planparadigmer - det rationalistiske, det inkrementelle og det deltagerorienterede - for på dette første abstrakte plan at udrede forskellene i udgangspunktet for planlægning. En kommunikativ planlægning er hverken ekspertstyret mod bestemte mål, som det er tilfældet med den rationalistiske planlægning, eller interessedrevet som den inkrementelle forhandlingsplanlægning. Den lægger vægt på borgerdel- 
tagelsen som medvirkende ved identifikationen af såvel mål som midler i planlægningen, og den anser også udfaldet af planprocessen som noget, der ikke bør kontrolleres af nogen enkeltgruppe og slet ikke på forhånd. Processens udgang afhænger af netop processen og dens konkrete forløb.

Videre, på det andet abstrakte plan, anvendes den kritiske teoris forståelser både af samfundet som både system og livsverden og af, hvorledes handlen foregår enten $i$ en systemisk handlekoordinerende kontekst eller med livsverdenen som handlekoordinerende. Dette vedrører såvel institutioner som individer ud fra den forståelse, at det altid er individer, der handler, også når det sker inden for institutionelle rammer. På analysens andet abstrakte plan anses de rationalitetsbegreber, der kan knyttes til disse handlekoordinerende kontekster, som afgørende for planlægningens indhold, og de analyseres i forhold til, hvilke aktører i planlægningen, der kan bevirke dem inddraget i planlægningens tiltag. Borgerne har, vises det, en kernerolle, da det er dem og kun dem, der kan tilføre rationalitetens etiske og æstetiske aspekter, uden at disse instrumentaliseres. $\mathrm{Og}$, ligeså afgørende, kun gennem dannelsen af kommunikativ magt i borgerdeltagelsen, kan disse aspekter bringes frem til beslutningsfasen og påvirke planlægningens endelige resultat. Borgerdeltagelsen med disse aspekter ses som helt afgørende for, at bæredygtighedsperspektivet i by- og miljøplanlægningen kan fremmes.

Endelig fremkommer så et tredje lag i analysens abstraktion, som er det mest konkrete, nemlig korte konstateringer af en dominerende situation for planlægningen, hvor de politiske, de økonomiske og de planmæssige forhold modstilles. Dette lag er nødvendigt for at kunne vise, hvorfor det er så afgørende, at alle rationalitetsformer inddrages i planlægningen.

Derigennem nås et andet magtbegreb i den kommunikative planlægning i forhold til den rationalistiske og den inkrementelle planlægning, hvor magt er henholdsvis ekspertmagt og investormagt. I den kommunikative planlægning kan vi, foruden politisk institutionel magt, tale om borgenes kommunikative magt. Denne borgermagt bliver konciperet som en modmagt. Karakteristikken kommer af, at planlægningen i de seneste årtier i allerhøjeste grad har skullet leve op til en situation, hvor den politiske magt svækkes parallelt med en tiltagende økonomisk dominans på alle niveauer, lokalt, nationalt, regionalt og globalt. Blandt andet på grund den stærkt stigende globalisering og internationalisering af økonomien. Samtidig aktualiserer de samme mekanismer behovet for langsigtet planlægning på de selvsamme niveauer, og derfor tales der om en modmagt, som kan udspringe af borgerdeltagelsen. Da den ikke kan eller bør være absolut, tales om modmagt.

Modmagten anses for absolut nødvendig for at realisere langsigtet planlægning, i lyset af de enorme udfordringer med eksempelvis klimaforandringer, befolkningsmigrationer, bæredygtig udvikling og social forandring og stabilitet. Endelig betragtes den skitserede form for kommunikativ planlægning som et afgørende indspil i udviklingen af samfundenes demokratiske 
beslutningstagen med hensyn til at bevare deres sammenhængskraft i globaliseringens tidsalder, der ikke blot byder på den økonomiske internationalisering, men også på en blanding af befolkninger og kulturer. Borgerdeltagelsen som modmagt kan medvirke til planlægningens langsigtede indhold og perspektivering og derigennem en politisk reaktivering af demokratiske beslutningsprocesser, der kan styrke samfundets bæreevne.

\section{Noter}

Foruden en tak til redaktionen for grundigt redaktionsarbejde og forslag vil jeg gerne rette et stort tak til Klaus Rasborg og Eskil Elling for gennemlæsning af første udgave af manuskriptet og mange værdifulde kommentarer og forslag til forbedringer.

1. Forvalterne er både de politiske beslutningstagere og deres ansatte planlægningseksperter, og som ydermere også kan være bygherre.

2. Begrebet instrumentalisering anvendes her og i det følgende i betydningen: at gøre en handlen, herunder en handlings anvendelse af viden, formålsbestemt, dvs. at handlingen gøres formålsorienteret selv om dens oprindelige afsæt kan være forståelsesorienteret. Dette omfatter således også viden, der oprindeligt er tilvejebragt i en forståelsesorienteret proces, men som anvendes i en formålsorienteret proces. Som det vil blive mere aktuelt i det følgende, kan dette også omfatte, at en handlen af konteksten gøres formålsbestemt uanset den handlendes selvforståelse, hvad angår med hvilket rationale handlingen udføres. Se f.eks. Elling 2003:336-350.

3. Bygherren kan både være en selvstændig aktør, som forvalterne skal tilvejebringe en planlægning for, eksempelvis når der til et privat anlæg skal tilvejebringes en VVM undersøgelse og en godkendelse eller en lokalplan, før byggeriet kan sættes i gang, og bygherren kan også være både bygherre og forvalter, når der f.eks. skal tilvejebringes en ny kommuneplan eller en lokalplan for et offentligt byggeri.

4. Deontologisk argumentation vil her sige, at borgerne må kunne orientere deres argumenter mod gensidig forståelse af, hvad processen bør handle om og opnå, og ikke mod et på forhånd givet mål. Eksempelvis at processen er målsættende eller målsøgende med hensyn til, hvad der kan optimere et miljøhensyn og indrette planen herefter, og ikke omvendt at indrette et miljøhensyn i planen efter et på forhånd givet mål, og på den måde varetage et miljøhensyn under forudsætning af en realisering af det på forhånd givne mål. I det sidstnævnte tilfælde gøres varetagelsen af miljøhensynet til et middel til at realisere det givne mål.

5. Dette begreb udvikler Habermas i sit demokratiteoretiske hovedværk Faktizität und Geltung. Frankfurt a. M., 1996, jf. nedenfor.

6. Habermas taler også om forskellige typer diskurser, herunder også etisk-politiske og moralske og juridiske diskurser, der altså også indeholder f.eks. normative udsagn om goder, og som indgår i politiske forhandlinger og beslutninger. Det vil føre for vidt at gå videre med dette her, jf. Faktizität und Geltung s. 195-207, 218-225.

7. Århuskonventionen eller UNECE's konvention om adgang til oplysninger, offentlighedens medvirken og klageadgang på miljøområdet, vedtaget i Århus den 25. juni 1998.

8. Jf. her den europæiske sammenslutning Covenant of Mayors (Borgmesterpagten), som netop er dannet af europæiske kommuner for at imødekomme disse udfordringer. http://www.eumayors.eu/IMG/pdf/covenantofmayors_text_da.pdf

9. Naturligvis kan der også internt mellem borgerne være interesse- og holdningskonflikter. Men i modsætning til de øvrige aktørgrupper, der er diskuteret her, er borgernes interesser og holdninger ikke systemisk givne, men noget der frit kan antages af de enkelte borgere. Desuden er borgernes handlen i processen orienteret mod at komme til indbyrdes forståelse om sådanne konflikter, for derved at fremme en fælles indsigt og indflydelse. 
10. Indenfor empowerment-traditionen tales om såvel mægtiggørelse, der refererer til de formelle rammer eller mulighedsrummet for individers eller en gruppes faktiske medvirken, som myndiggørelse, der refererer til udviklingen af individer eller grupper, så de bliver i stand til at udnytte disse muligheder (Andersen 2007). Mægtiggørelsen kan således ikke blot betragtes som tilvejebragt via etableringen af de formelle krav til borgerinddragelsen i planlægningen, men må netop ses som de faktiske inddragelsesprocesser dvs. at planlæggerne de facto tilstræber inddragelse. I forhold hertil bliver myndiggørelsesaspektet endvidere centralt ved, at det også er i planlæggernes interesse at medvirke til myndiggørelsen af svage eller marginaliserede grupper, således at også disse faktisk er i stand til at bidrage til planlægningen. Derved bliver det også muligt at sidestille myndiggørelse med ansvarliggørelse.

11. Begrebet modmagt har flere oprindelser og refererer grundlæggende til, at en manifestation af magt medfører en eller flere modpoler - at asymmetriske magtrelationer skaber modstand. Oprindeligt er det fra den tidlige marxisme, hvor arbejderklassen kan skabe sig selv som modmagt til kapitalens herredømme. Altså modstand og magtovertagelse. Også Foucault brugte modmagtsbegrebet i sine formuleringer om magt og modstand (han skriver, at "Hvor der er magt, er der modstand" og fortsætter: "og dog, eller snarere derfor, står denne modstand aldrig i en ekstern relation til magten", Viljen til viden, side 101). Empowerment-traditionen har ligeledes en reference til modmagtsbegrebet, når den taler om, at nogle gruppers magt skal styrkes $\mathrm{i}$ forhold til de magtrelationer, som de umiddelbart står magtesløse overfor. Modmagt er således, i overensstemmelse med ovenstående om magtens relativering, ikke en selvstændig eller permanent kraft, men opstår i relation til andre magtformer.

12. Her kan henvises til det for nyligt på dansk udgivne værk af den franske sociolog og filosof Jacques Rancière: Hadet til demokratiet, der netop undersøger den i moderniteten så udbredte selvforståelse blandt de uddannede eliter, at de uvidende masser kun leder "demokratiet" på afveje med deres "populisme", "narcissisme", "forbrugerisme", "egoisme", mv.

\section{Litteratur}

Agger, A. 2007: "Kommunikativ planlægningsteori - nye idealer for borgernes deltagelse i planlægningen", i Jensen, A., Andersen, J., Hansen, O.E. og Nielsen, K. Aa. (red.): Planlægning $i$ teori og praksis - et tværfagligt perspektiv. København: Roskilde Universitetsforlag, pp. 31-45.

Andersen, J. 2007: "Empowermentperspektivet, i planlægning", i Jensen, A., Andersen, J., Hansen, O.E. og Nielsen, K. Aa. (red.): Planlægning i teori og praksis - et tværfagligt perspektiv. København: Roskilde Universitetsforlag, pp. 46-62.

Becker-Schmidt, R. og Knapp, G-A. 1987: Geschlechtertrennung - Geschlechterdifferenz. Suchbewegungen Sozialen Lernens, Bonn: Dietz Verlag.

Dryzek, J. 1992: "Ecology and discursive democracy: Beyond liberal capitalism and the administrative state". Capitalism, Nature and Socialism, 3(2):18-42.

Dryzek, J. 1997: The Politics of the Earth - Environmental Discourses. New York: Oxford University Press.

Elling, B. 2003: Modernitetens miljøpolitik. København: Frydenlund.

Elling, B. 2007: "Miljøvurderinger - også en kamp mellem viden og interesser", i Jensen, A., Andersen, J., Hansen, O.E. og Nielsen, K. Aa. (red.): Planlægning $i$ teori og praksis - et tværfagligt perspektiv. København: Roskilde Universitetsforlag, pp. 327348.

Elling, B. 2008: Rationality and the Environment. London and Sterling, VA: Earthscan/ Routledge.

Elling, B. 2013a: "Kritisk Teori", i Fuglsang, L., Olsen, P.B. og Rasborg (red.): Videnskabsteori i samfundsvidenskaberne. På tværs af fagkulturer og paradigmer, 3. Udgave. København: Samfundslitteratur, pp. 137-170. 
Elling, B. 2013b: "Hvem bestemmer?". Byplan, Nr. 3(65):18-19.

Eriksen, E.O. \& Weigaard, J. 2003: Kommunikativt demokrati. København: Hans Reitzels Forlag.

Fischer, F. og Forester, J. 1993: The Argumentative Turn in Policy Analysis and Planning. Durham, N.C.: Duke University Press.

Fischer, F. 2000: Citizens, Experts and the Environment - The Politics of Local Knowledge. Durham, N.C.: Duke University Press.

Foucault, M. [1976] 1994: Viljen til viden. Seksualitetens historie 1. København: Det lille forlag.

Friedmann, J. 1987: Planning in the Public Domain: From Knowledge to Action. Princeton, NJ: Princeton University Press.

Gregers, Ole 2013: "Miljøvurdering - er det kun bøvl og ekstraarbejde?". Byplan, Nr. 2(65):20-26.

Gregersen, T. 1996: "Habermas' diskursteori om politisk demokrati". GRUS nr. 48(17): 5-32.

Gualini, E. 2010: "Governance, Space and Politics: Exploring the Governmentality of Planning", i Hillier, J. og Healey P. (eds.): The Ashgate Research Companion to Planning Theory. Surrey: Ashgate, pp. 57-85.

Habermas, J. 1996a: Teorien om den kommunikative handlen, Aalborg: Aalborg Universitetsforlag.

Habermas, J. 1996b: Diskursetik - Notitser til et begrundelsesprogram. Frederiksberg: Det lille Forlag.

Habermas, J. 1998: Faktizität und Geltung. Frankfurt am Main: Suhrkamp Verlag.

Hansen, H. P. 2007: Demokrati og Naturforvaltning - en kritisk sociologisk-historisk analyse af nationalparkudviklingen i Danmark. Institut for Miljø, Samfund og Rumlig Forandring, Roskilde Universitet, PhD-afhandling.

Healey, P. 1996: "Planning Through Debate: The Communicative Turn in Planning Theory", i Campbell, S. og Fainstein, S. (eds.): Readings in Planning Theory. Oxford: Blackwell Publishing, pp. 234-257 (2. udgave af Wiley 2003 og 3. udgave af Wiley 2011).

Hillier, J. 1998: "Representation, Identity, and the communicative shaping of place", i Light, A. og Smith, J. 1998: The Production of Public Space. Maryland: Rowman \& Littfield Publishers, Inc., pp. 207-232.

Hillier, J. 2002: Shadows of Power: An Allegory of Prudence in Land-Use Planning. London /New York: Routledge.

Hillier, J. 2010: "Introduction to Part Three", i Hillier, J. og Healey, P. (eds.): The Ashgate Research Companion to Planning Theory. Surrey: Ashgate, pp. 367-398.

Hoch, C. 1996: "A Pragmatic Inquiry about Planning and Power", i Mandelbaum, S.J., Mazza, L., og Burchell, R. W. (eds.): Explorations in Planning Theory. New Jersey: Rutgers, The State University of New Jersey, pp. 30-44.

Innes, J. E. 1998: "Information in Communicative Planning". Journal of the American Planning Association, 64(1):52-62.

Innes, J.E. og Booher, D.E. 1999: "Consensus Building as Role Playing and Bricolage, Towards a Theory of Collaboratory Planning". Journal of the American Planning Association, 65(1):9-25 og 65(4):412-423. 
Innes, J.E. og Booher, D. E. 2000: "Planning Institutions in the Network Society: Theory for Collaboratory Planning", i Salet, W. og Faludi, A. (eds.): The Revival of Strategic Spatial Planning. Amsterdam: Royal Netherlands Academy of Arts and Science.

Jensen, A., Andersen, J., Hansen, O.E. og Nielsen, K. Aa. 2007: "Planlægning i teori og praksis - en tværfaglig lærebog", i Jensen, A., Andersen, J., Hansen, O.E. og Nielsen, K. Aa. (red.): Planlægning i teori og praksis - et tværfagligt perspektiv. København: Roskilde Universitetsforlag, pp. 9-27.

Lindblom, C. 2003: "The Science of "Muddling Through"', i Campbell, S. og Fainstein, S. (eds.): Readings $i$ Planning Theory, 2nd edition. Oxford: Blackwell Publishers, pp. 196-209.

Miller, D. 1992: "Deliberative democracy and social choise". Political Studies, 40 (Special Issue):54-67.

Nielsen, H. 2012: Offentlighed, mellem deltagelse og legitimering - et demokratiteoretisk perspektiv på vandplanlægningen i Danmark. Institut for Miljø, Samfund og Rumlig Forandring, Roskilde Universitet, PhD-afhandling.

Nielsen, K. Aa. og Nielsen, B. S. 2007: Demokrati og Naturbeskyttelse - Dannelse afborgerfrllesskaber gennem social læring - med Møn som eksempel. København: Frydenlund.

Rancière, J. 2013: Hadet til demokratiet. København: Forlaget Møller.

Stanton, J. 2014: Democratic Sustainability in a New Era of Localism. New York: Routledge.

Verma, N. 2010: "Governance and Planning: A Pragmatic Approach", i Hillier, J. og Healey P. (eds.): The Ashgate Research Companion to Planning Theory. Surrey: Ashgate, pp. 399-412.

Versteeg, W. og Hajer, M. 2010: "Is This How It Is, or Is This How It Is Here? Making Sense of Politics", i Hillier, J. og Healey P. (eds.): Planning Theory. Surrey: The Ashgate Research Companion, pp. 159-182.

\section{Konventioner:}

http://www.eumayors.eu/IMG/pdf/covenantofmayors_text_da.pdf

Århuskonventionen eller UNECE's konvention om adgang til oplysninger, offentlighedens medvirken og klageadgang på miljøområdet, vedtaget i Arrhus den 25. juni 1998. 